\title{
Socio-cultural Life of Dura: A Sociological Case Study From Khaje Gaun, Lamjung
}

\author{
Bishow Bandhu Adhikari
}

\section{Background}

Nepal is a small country, characterized by socio-cultural and geographical diversity. Nepal is a multi-ethnic, multi religious and multi lingual country and for this reason the folk traditions and folk literatures here have their own unique characteristics. Because of this the study of human civilization and cultural heritage is significant from sociological and anthropological point of view. These days the cultural heritages and identity of these ethnic groups is in danger because of modernization, acculturation, lack of scientific research and lack of proper protection. Among the many ethnic groups of Nepal only 59 fall under the category of ethnic groups. Most of those aboriginal and ethnic groups are politically weak and disadvantaged (Tenth Five Year Plan, 2059: 483).

Lamjung district of Gandaki Zone is one such place. It is gifted with the beauty of nature and it is grated with world famous mountain ranges adding to this the rich folk cultures of various castes and ethnic groups. In the south west of the district lies a serpentine mountain range popularly known as Duradanda. Durandanda boasts a glorious history and has played an important role in bringing educational awareaness. Dura Danda is the main dwelling place of Dura people and it is related to the establishment and history of Shah Dynasty. Since, Dura people lived here first, it is known as Dura danda. Altogether Six VDCs fall under this historical place. These VDCs are Chandreshwor, Dhusryani, Purankot, Sindure, Ratnadevi and Duradanda. Dura ethnic group is one of those many ethnic groups who have been living here for a long time. Dura people have started to live in 12 different districts ${ }^{1}$ of the country. According to the statistics available at the end of year 2054 by the central office of the society for the service of Dura people is located in Kathmandu. However Dura danda of Lamjung district is the main dwelling place of these people.

This study is centered on the Duras whose main dwelling place has been Lamjung and who are economically, socially, educationally and politically backward and are also deprived of many facilities enjoyed by the people belonging to other ethnic groups. This study will also touch upon the impact of modernization on the culture of these people and how their original culture is in danger of extinction. This study has selected Khaje Gaun the ward no 4 and 5 of Chandreshwor VDC of Dura danda, Lamjung as the area of study. The objectives and the major areas of the study were:

1) A brief introduction to the historical background of Dura people.

2) Introduction to the main rites of Dura people from birth to death.

3) A study of the unique features of festivals, family structure and food and dress of these people.

4) The changes that have emerged in the culture of these people and the impact of modernization.

Since it is practically difficult to study the whole of Dura danda, this research was focused on the wards 4 and 5 of Chandreshor VDC which has be selected on the basis of Area cluster sampling. The selected area is known as Khajegaun.

\footnotetext{
- Teaching Assistant in Sociology at Mahendra Multiple Campus, Baglung

${ }^{1}$ Lamjung, Kaski, Tanahun, Chitwan, Rautahat, Rame Chhap, Okhaldhunga, Kailali, Doti, Nawalparasi, Kathmandu and Lalitpur
} 
As the research is anthropological it requires indepth field study but field study of short duration was under taken. The study was conducted on the basis of quasi-participatory observation. For the purpose of this study two types of data are used. The first type includes the primary data incorporated from the interviews, questionnaire and necessary observation related to the Dura people. Notes have also been taken about the Duras with the help of the interviews with the people who know and have some knowledge of Dura people. Available literature on the Dura people has been used as secondary sources of data. Although Duradanda is the main dwelling place of the Duras, some differences have been noticed between them and the Dura living elsewhere.

The Dura people had aligned with the other people to overthrow the tyrannical rule of the then Ghale rulers and establish the rule of Shah Dynasty. Khaje Dura the brave fore father of the present Dura people was born in and had been brought up in the Khaje Gaun which was named after him. A statue of that brave forefather was built in 2033 B.S. as a tribute to him. The area around the statue is called Khaje park. The people of this area have been celebrating Khaje Dura jayanti every year on the $21^{\text {st }}$ of Kartik by organizing various programmes. The total number of Dura households were 47 and the total population is about 266 (males 127 and females 139) (Adhikari, 2055). In addition to the Duras other people also live in this place.

\section{The People: Duras}

Who are the Duras? Where did they originally come from? According to the statistics made available by the National population census 2058, Dura people comprise (5169) $0.02 \%$ o the total population of Nepal. However, according to the statistics provided by the society for the service of Dura people (towards the end of 2054 B.S.) the total population of Dura people is 5676 and the largest number of them (40.9) live in Lamjung itself.

Some scholars and researchers have tried to answer these questions, but there is no uniformity about what they have said. Since there is no consensus among these scholars no single view is adequate and its hard to pinpoint how they came there and who they actually are. However the views and opinions of scholars and the genealogy they have prepared enable us to say, what follows.

Duras entered Lamjung through Chitaudgorh from, Jajarkot, Rukum, Parbat, Duronkot, Arghaun and Durathum of Kaski (Yogi 2012: 98). Due to many adverse Circumstances the descendents of the king of Dullu Dailekh Dynasty came to Lamjung through Rudra Bhot in coure of migration. Hear say has it that since the Dulal people came to Lamjung through Rudra Bhot the name got disforted and began to be called Rudura which ultimately became Dura (Gurung- 2051/52:178).

The forefathers of the people used to work in the palace of the Rajputs of India. According to a popular legend, one the Musalmans attacked the Rajputs and the Rajput women came and settled in Lamjung along with the servants they had brought with them. The descendents of these were the Duras (Mechi Mahakali 2031:195). Walter Frank has said that Duras were the product of the marriage between the Magars and the Gurungs (Praguya 2051/052:179). The surname of the ancient forefather of these Dura people was Dulal and the ancient kings of Dulha Dailekh dynasty were the forefathers of these people and since they came to Lamjung through Pudrabhot they chose the surname Dura for themselves leaving out the surname Thapa (Adhikari 2042:2). According to the genealogy of the Duras, by late Pitamber Thapa the Duras were originally of Dulal surname and were later called Duras as they come through Durankot of Parbat (Gurung 2049:9). 
Despite the attempts to find affinity between the Dulals of Durankot, Rudrabhot Dullu and the Duras there is lack of adequate data and facts to justify the link. But the idea that the Duras were linked to the Dulal Dynasty is reliable on the basis of the genealogy of the Dura people. Since these people have their own language and culture its not just to say that they were the product of marriage between the Magars and the Gurungs. Put to the absence of historically proven facts it would also be unjust to say that these people were the descendents of the Rajput women and their servants.

As there is no consensus among scholars and researches about the genealogy, surname and ethnic identification, there is also no written proof about where they came from. In his research paper Nagendra Sharma has said that the Duras have been living in Lamjung for the last $2 / 3$ hundred years (Sharma 2037:58). The red seal of these people is found to be 933 years old and on the statue of their brave forefather Khaje Dura it is written that they brought Yeshobrahma Shah to Lamjung and placed him on the throne. There findings try to establish that the Duras came to Lamjung 7 or 8 generation ago and started living there. There is no practice of untouchability and caste hierarchy among these people. There is no sub-caste in the Dura people and their caste status is determined on the basis of surname. Four surnames are found among the Duras, of the study area.

\begin{tabular}{cc} 
Thar (Sub-clan) & Gotra (major Clan) \\
\cline { 2 - 2 } Dhingal & Kausil gothra \\
Puhi & Shrista " \\
Kyapchha & Madhu " \\
Parche & Atri " \\
Dorde & \\
Kharbare &
\end{tabular}

People of other castes have 12 star signs and 12 months while the Dura people have twelve barga/categories ${ }^{2}$. This class order starts from the $15^{\text {th }}$ of Paush of every year and ends with the $14^{\text {th }}$ of paush of the next year. When this order is complete one year is thought to have been completed. This system of class or barga takes into consideration especially during marriage. Care is taken when the question of marriage between opposing barga. In such case marriage is not entertained. While they count age on the basis of these barga they are found to make use of Nepali and English calendars for other purposes.

Physically Dura people look like Mongoloid. They are considered as Matwali. They are friendly and honest. They don't pick up a fight first but if provoked they don't withdraw. Other characteristics of Dura people are that they join military service and are fond of hunting and fishing. Females have a fondness for ornaments. Females enjoy dancing and singing. But due to new changes traditional thinking has also changed. Studying, holding jobs, taking part in modern recreational activities and wearing modern dresses are also a part of their activities.

\section{Kinship relationship}

Generally kinship means the relationship between people that result from birth and marriage. As in other castes kinship system among Dura people has three tiers. This relationship plays an important role in familial and other fields of social cooperation.

\subsection{Consanguineous relationship}

\footnotetext{
2 - rat, cow, tiger, cat, falcon (garud), horse, sheep, monkey, bird, dog, pig (bandel).
} 
This relationship is maintained from the side of the male and the surname of the male is retained. Even if the line of blood relationship is long among the Duras, marriage is allowed and they have to observe death pollution for such relations.

\subsection{Affinal relationship}

Affinal relationship has its own social meaning and importance. Marriage establishes an intimate relationship between two families. Dura people establish affinal relationship with in their own caste/ ethnicity.

The relationship besides the blood and the affinal comes under this type, which is also called fictive kin relationship. Intimacy between people of the same or different castes leads to this kind of relationship. Duras may establish this relationship with Gurungs, Magars and Brahmins. This relationship is maintained at personal level. However this kind of relationship has been on decline in the last few years.

\section{Dura Language}

Nepali is the language of the nation and there are other many languages of different people. But due to the lack of proper protection and patronage the language of the minority groups are at the risk of being pushed out of existence. Dura language of Dura people is a case at hand. We can not say for sure whether Dura people have their own script but some old people of Dura community claim to have had their own language even though there is none in existence now. This is clear from the fact that Rishikanta Adhikari has given a few Dura words and their meaning in his book. (Adhikari 2042). Presently the Dura people use Nepali language as their mother tongue.

\section{Occupation}

In the past there was a tendency among the Dura people to join the military service in foreign countries. Due to increase in educational awareness, the tendency of farming and livestock production is declining. Their economic life is not satisfactory.

\section{Education}

Duradanda of Lamjung district is considered to be the center of educational awareness. Unfortunately, while the people of so called upper castes are educated the people of so-called lower castes and ethnic groups are educationally backward. Backwardness in education has resulted from the tendency to go to foreign countries and the decreasing concern for learning. These days, even though the number of Dura people attending school is satisfactory the number of students doing higher studies is disheartening.

\section{Dura religion}

From the point of view of physical build and nature Dura people look like Mongolions but they have been following the religious practices of the people of Aryan culture. These people have also been influenced by Buddhism. Since these people have lived and interacted with the people of other religions and culture there has been a mixed impact on the religion and culture of these people. Dura people are also involved in the religious activities like building taps, roads and Chautaras. They keep and worship cows and use the urine, milk, ghee, curd of cows in different religious (activities) ceremonies. They worship and follow gods and goddesses like Shiva, Ganesh, Swosthani, Satyanarayan and Kalika. They invite a Brahmin priest to their home for conducting different religious ceremonies. They invite a lama for various religious ceremonies and rites meant to pay tribute to dead forefathers and relatives. They consult local witch doctors for curing different diseases and also believe in witches. These things have been learnt from the field study. They stay clean and pure while worshipping different gods and goddesses. They are found to believe in the idea of hell and heaven. Finally, they declare themselves to be the 
followers of Hinduism. Dura people believe in divine power and worship gods and goddesses and sacrifice animals to gods to fulfill their wishes. They also worship their own traditional deities like Kalika Devi, Vayu, Bhangeri, Chandi, Shanishchare, Muluki and Bhimsen as well as clan (deity) god.

\section{Some Social practices (Parthas)}

\subsection{Mother's group}

Traditionally Dura people have been building resting places (Chauraras) and have been involved in many other service oriented social activities. However the form of these activities has changed over the years. Now, they have been involved in building, wells, roads, taps, and temples by organizing mother's groups and other clubs. They are found to be very active in such traditionally practiced activities.

\subsection{Parma System}

Parma is a traditionally followed system among Dura people. It is the system of exchanging labour during planting and harvesting seasons. Nowadays the system of hiring labourers has taken over the traditional practices.

\subsection{Rodi}

Though Rodi is integral to Gurung culture it has also taken roots among Dura people. Rodi is recreational in nature where the young males and females gather at a place to forget their worries and anxieties. After a day's work these young people assemble at a place and enjoy singing and dancing to overcome the exhaustion from the day's work. Nowadays this system is threat of existence due to the impact of modernization.

\section{Major rites and rituals of Dura}

If we look at the origin and history of Dura people we find three groups (janajatis) among them namely, touchable, and Matwali, of the sixteen rites in Hinduism ten rites are famous in particular. The rites of Dura people are similar to those of Hindus and Gurungs with whom they are very close. The main rites of the Duras are life cycle rituals, which starts from naming of new born baby, performance of Chhaiti ( $6^{\text {th }}$ day rites), rice feeding, put pute (celebration of son birth), chhewar (first time hair saving rite), marriage and death (funeral rites).

Immediately after the child is born the birth cord is cut and the time of birth is recorded. On the eleventh day the child is given a name and is made pure or touchable by sprinkling cow urine. Most of the Duras invite a Brahmin priest for performing the rites but the people of Dorde Surname invite a Lama. After a child is born the mother and the child are kept in a separate place and away from people until the naming ceremony is performed. As they believe that the $6^{\text {th }}$ day is when the destiny of the new born is determined. People gather at that house and enjoy singing dancing and feasting and stay awake whole night. Rice feeding ceremony is performed after 6 months in the case of a male child and after 5 month in the case of a female one. Dura people perform this rite according to their economic status. After two years they perform putpute, for the eldest son but nowadays this is declining. Chhewar is the rite which is performed after the naming ceremony and rice feeding ceremony of a male child is performed. This is also known as rite of passage or socialization. Chhewar is the rite of cutting the child's hair for the first time. Like the people of other ethnic groups chhewar is also practiced by Dura people. After chhewar a child is considered fit to take part in many religious and social activities. If a son reaches an odd year $(3 / 5 / 7)$ of age he is sent his maternal uncle's house and his uncle will take him to a cow shed, 
tie him with a rope and then will shave his hair. After this the baby is given delicious food and is sent back to his own house. Nowadays these rites are not regularly performed.

Dura people also take marriage as an important rite in life. Bajaune Bibaha, Nabajaune Bibaha and love marriage are practiced. Marriage conducted with the help of a matchmaker (kaliya) and consent of parents is known as Bajaune Bibaha. According to which, the girl and the boy to be married are sent away to a certain place and are welcomed back with the consent of parents Nabajune Bibaha. Marriage relationship between brother's daughter and sister's son is in vogue marriage to be held the surname clan and Barga have to match. The marriage that is done between girls and boys who have fallen in love with each other is also acceptable in Dura community and it is called love marriage. In addition to these, if a man elopes with a married woman it is a marriage involving alimony. Decision of divorce is taken socially. A man or a woman willing to get divorce will have to pay certain amount of money to society. However, due to the new changes a tendency has developed to avoid love marriage, alimony marriage and divorce. Arranged marriage is considered to be ideal marriage by Dura people. Child marriage, polygamy and unmatched marriage are not practiced nowadays. Even though court marriage and widow marriage are legally recognized Dura people don't seem to practice them. Though the practice of inter caste marriage was prevalent in the past, it is not entertained now a days because it is considered good from social point of view.

Dura people have their own tradition and method of performing funeral rites (death rites) believing that the soul of dead people will rest in peace in heaven. The relatives of the dead souls perform the death rites by following all necessary rules. Hinduism and Buddhism both have an impact on Dura's method of performing the death rites. Even within the same group, sometimes the son-in-law and sister's son is invited and sometimes the Lama is invited to help perform the funeral rites. Dagbatti is offered to the dead body and the corpse is cremated (buried in the case of a child). The nearest one who observes mourning formally will shave their head. They wear white clothes. The period of formal mourning varies depending on the age of the dead person. It is observed for $1 / 2$ days if the dead is a small child and for $3 / 5 / 13$ days if the dead is an adult. Close relatives don't perform any religious or other programs until the period of mourning is over. On the last day priest is called and the mourners and the relatives of the dead become pure after they receive the holy urine of cow. Those who can afford will donate a cow. The mourners will wear white clothes for 45 days, 6 or 12 months if the circumstances are favorable. In the past female used to participate in the funeral procession but nowadays it has been discarded. Nowadays people of other castes/ ethnic groups can take part in the funeral procession. They are however, not allowed to touch the dead body. Previously people would eat fish and meat on the last day but this is not practiced nowadays. In the past a stupa used to be built near the site of burial but they have stopped it now due to density of population and due to the statue of Khajedura and part.

\section{Food and Dress}

For their day to day consumption Duras eat different dishes prepared from the food grains they have produced themselves. Usually they eat meat and fish. Since they keep cattle they use milk and milk products. On the occasion of feast and festivals they show hospitality to the guests by serving wine and meat. Nowadays they also buy different food items from the market.

The dress of Dura people is not very different from the dress of other people. As for the traditional dress worn by males-Kachchhad, Sash, Bhoto, waistcoat, cap and gadi are typical. Whereas females wear Chhitka, Gunju, Ghalek, Cholo, Tikis, Majetro, Dhoti, and embroidered lungis and sash are typical. As for the traditional ornaments women use Butte marbadi, Naugedi, 
Jartar, Kantha, Dhungri, Silmundri, Phuli, Bulanki, Ring, Chandrama are the typical ones. However, nowadays, they have started using the dress and ornaments as per their wishes and capacity. Traditional dress and ornaments are used by the old and the young on certain special occasions only. 


\section{Family structure}

Joint family was prevalent among the Dura people in the past due to the lack of alternative sources of income except agriculture. The question of labour was also one of the reasons for this family structure in past. Now, due to increasing population and the availability of alternative sources of income people desire freedom from the cares and responsibilities of joint family. Individualistic thinking is also one reason for the change. A tendency to live separately after marriage has developed and they are moving toward nuclear family structure. The people of new generation do not like to adhere to the norms and values of the joint family structure. Field study helped us to understand these changes.

Patriarchal social system is dominant in the Dura people. Male member is the head of the family and he gives the final decision on every matter. But females take charge of the domestic chores and are entrusted with the family treasure. Males leave home and take part in different external activities whereas females are confined within the walls of the home. There is a tradition of respecting old people and women among the Dura people. Males have been playing a dominant role in raising educational awareness among their people.

\section{Major Festivals}

Every caste and ethnic group has its own festivals. These festivals have their own unique values and features. In a country like ours where Hindu religion and philosophy is dominant there are some common festivals celebrated by people belonging to different castes and ethnic groups. On the other hand there are also festivals which are unique to certain communities as per their tradition. Many festivals of the Dura people have an affinity with Hindu culture and religion. Besides, there are some festivals which are related to nationality, history and society. Some of the major festivals celebrated by Dura people are described below in brief.

\subsection{Baishakh Purnima}

On the day of this festival all the villagers gather together to worship the Ista Devata, Chandi Deurali. They either offer egg or sacrifice cock to Chandi. After they return from the place of worship, they again worship that god by making a sacrifice of a crowing cock. In such worship they set up a Kundal in the cow shed with cow dung. People visit their relative and perform dance during the festivals.

\subsection{Shrawan Sakranti}

On this day, people collect different plants from jungle and worship the Baraha god at night. They think that this will enable them to get rid of scabies after the worship. On the following day people are prohibited to do any kind of outside work because this day is known as 'Ragat Barne'.

\subsection{Teej}

Like other communities, Duras also celebrate Teej festival but they don't observe fasting like Brahmins and Chhetris. However they invite their daughters and sisters and respect them.

\subsection{Bada Dashain}

Like people of other communities Dura people celebrate Dashain with much gusto and gumption. On the first day of Dashain, they sow wheat and maize seeds for the purpose of growing jamaras either in the house or at the place of sacrifice where goddess Kalika is worshipped. If they have promised to offer something they worship in Kalika temple. On the seventh day they observe fulpati. On the $8^{\text {th }}$ day Dura people go to the temple with a folk band that plays traditional music and sacrifice goats on the ninth day. On the very day of Dashain they put tika on forehead and 
wear jamaras. Tika is also put on doors and windows. Juniors receive tikas and blessings from the seniors. In the past, there was a tradition of offering tika to 7/5/3 virgin girls who were believed to be goddesses. Elderly people say that the other people received tika only after the girls are given tika. This tradition has changed now. People put tika until the day of Purnima.

\subsection{Tihar}

Like other people the Duras also celebrate Tihar. Tihar is celebrated for five days. During these five days crow, dog, cow, ox and brothers are worshipped. Brothers are worshipped on the day of Bhaitika which is the concluding day of the Tihar festival. On the day of Laxmi Puja people enjoy gambling and play Bhaili. Young people and especially mother's group play Deusi and Bhailo. The way Duras celebrate Tihar has been affected by the way of Brahmins and Chhetris.

\section{6 $21^{\text {st }}$ of Kartik}

On this day celebrations take place in memory of their brave forefather Khaje Dura. The then Ghale kings were defeated and Shah Dynasty came into existence owing to the valory of their gallant forefather Khaje Dura. His statue was erected in Chihanpata in the year 033 B.S. Every year $21^{\text {st }}$ Kartik is celebrated as Khaje Memory day. This day is celebrated by conducting various programmes.

\section{$12.715^{\text {th }}$ of Paush}

New Year of Dura people begins from the $15^{\text {th }}$ of Paush on this day Barga changes and the extra years they have lived are counted. Many enjoyable programmes are held on this day.

\section{2. $827^{\text {th }}$ of Paush}

On this day all the academic institutions, different organizations and offices in Duradanda organize meetings and ceremonies as well as other competitive programmes along with rally to celebrate the day in a grand manner. This day is celebrated in Sindure Dhunga which is located in Sindure village development committee. This day is believed to be the day on which Khaje Dura had offered sindur to Yesho Brahma Shah in Sindure Dhunga as part of the process of establishing Shah Dynasty. In addition to this, this day is also celebrated as the birth day of king Prithivi Narayan Shah, who is supposed to be the symbol of national unity.

\subsection{Maghe Sakranti}

On the last day of Paush delicacies are prepared. At night people go to their tap and sing the whole night and make a big fire. The following day is the Maghe Sakranti, people go to the tap and women wash their husband's feet and drink that water. Likewise, they drink the water that has been used to wash the feet of their daughters and son-in-law. After that they offer tikas to virgin girls and give presents as per their capacity. Lastly they relish the delicacies prepared the night before. 


\subsection{Falgun Purnima}

On this day no worship of any god is done publicly. However, if a promise was made to the god, the worship is performed. Especially the young enjoy playing colors as holi.

\subsection{Chaitra Dashain}

In their public kot, the Turlung kot, Dura people worship Durga Bhawani for nine days. At home they sacrifice birds and animals. For three days i.e., from the day of Saptami to Nawami they conduct different games, competitions and various performances such as hymns and songs and other programmes at Turlung kot.

\section{The Relation of Duras with other people}

Unity in diversity is our nation's specialty. Basically caste divisions according to occupation in Hindu tradition sound practical from social point of view. Since this tradition is prevalent in village areas, inter caste relationship has become inevitable. In this context, as Dura are affected by Hindu cultural and religious tradition, they have an intimate relationship with Brahmans. They also receive help from Brahmin priests. They respect the Brahmins highly because they believe that Brahmins can play an important role in spreading consciousness among people and in eliminating the social discrimination. They also believe that Brahmins played a vital role in the democratic movement of 2007 B.S. Brahmins have also made attempts to research the lifestyle of the Dura people. Along with this, because of mutual give and take and for some social reasons Duras have had a good relationship with Brahmins as well as people of other communities.

\section{Changes seen in the life style of Dura People}

The social and cultural environment of Duras marked by originality is not the same today. As change is inevitable the life style of Duras has also undergone some changes over the years. Every ethnic group is subject to this law, but the degree of change has differed. Changes that have taken place in rural areas have been in a slow place compared to changes in urban areas. This process of social transformation covers three aspects, namely westernization, sanskritization and development (Gurung; 1989).

Like other ethnic groups, Dura are also a minority group living in the countryside. It is also a marginalized group. We notice certain changes in their socio-cultural life. Modernization has affected their cultural tradition in the past. When they came to Lamjung, the Brahmins were a dominant community as well as the Ghales and Chhetries. Since they were a small number, they were directly affected by the Gurungs, Brahmins and Chhetries. Because of this, their sociocultural life resembles with these communities. At the initial phase, Duras were deprived of any chance to join the military service as well as other services. So, they had to join such services posing themselves as Gurungs. Since they were compelled to do this, many of their rites, rituals and various aspects of their cultural tradition were affected by Gurung culture. The Duras who are now educated say this. Duras have lived in close proximity with Brahmins for a long time. In order to show affinity with Hindus, they worship Devi, Satyanarayan, Shiva and Kirishna etc. With the help of Brahmins they celebrate many festivals and adapted their rituals to those of Hindus. This is how they have been subjected to the process of Sanskritization.

The food and costumes of Dura people have also witnessed great changes. Though the system of exchange of labour, Rodi and other traditional songs, music and dance, Thettal, Cehantu, Sorathi and other Lok Bhakas specially "Dura Thado Bhaka" have their own unique and original features, these have been on the decline. The main cause behind the decline is the negligible population of elderly people who were carrying on with the tradition. More ever the remaining a number of elderly people are passive and incapable of continuing the tradition. Many young people have left villages in search of employment opportunities and the onset of modernization has caused the 
cultural tradition to decline. Besides, the lack of awareness among people for preserving the tradition is one of the reasons for the decline people go to foreign countries and when they return home they are people who have assimilated the foreign culture. This situation is also equally responsible for the decline of original Dura cultural tradition.

At present there is a resurgence of awareness and sense of identity due to the modern education they have got and the various programmess and activities initiated by the government and INGOs designed to uplift and protect the minorities. They are also enjoying freedom in different fields. Constitution has no prejudice towards any community. Due to these reasons awareness has spread among Dura people. Their improved position has allowed and made it possible for them to study about themselves and their socio-cultural tradition. They are working actively for their upliftment and advancement by establishing youth clubs, mother's group at local level and society for the service of Dura people at the central level. It shows that they have been actively working to reassert their old identity.

\section{Problems and Suggestions}

Centering on the given topic while studying the Khaje village under Chandreshwor VDC the following problems were found.

- $\quad$ Lack of availability of reliable data concerning the origin and history of Dura people.

- Lack of national recognition of a historical personality like Khaje Dura.

- Disappearance of the language of Dura people.

- Impact of modernization on their life and absence of their own specific and fundamental culture and religion due to the influence of Buddhism and Hinduism.

- Their social, economic and academic position is not strong.

- $\quad$ Decline of their cultural heritage.

To solve the above mentioned problems the following suggestions are put forwarded:

- $\quad$ Search for origin and history, reconstruction of language, the importance of Khaje Dura should be nationally realized.

- $\quad$ They should be made active for the preservation of their cultural heritage.

- There is a necessity of effective programmes such as skill development, practical and professional education and trainings so as to make them strong in socio-economic and academic field.

Finally, it is worth while to understand that until and unless all the castes and ethnic groups no matter which religion, language and culture they follow, are treated equally the development of the country as a whole is impossible since unity in diversity is our specialty. The language and culture of each and every marginalized group should be searched and preserved. Every ethnic group should have it's own identity. More over they should be made conscious so that they can become strong in all spheres of life. The main responsibility and obligation of the state and other institutions is to do the same. Strictly speaking, sociologists and anthropologists can't afford to be passive and should try their best to speak and write on behalf of the marginalized voice and communities.

Note: This article is based on field research, "Impact of modernization on the culture of Dura people, Lamjung Khaje Gaun: A micro study", which was carried out by the writer for the presentation to the Central Deportment of Sociology/Anthropology, in 2055 as partial fulfillment of the Master's Degree Course in Sociology. 


\section{References}

Adhikari, Rishikant 2042: Dura Jatiko Parichay, Lamjung

Barett, Richard A. 1984: Culture and Conduct, Wadsworth Publishing Company, California, USA

Bista, Dor Bahadur, 2032: Sabai Jatko Phulbari, Sajha Rakashan, Kathmandu.

Bista, Dor Bahadur 1972: People of Nepal, Ratna Pustak Bhandar.

CBS 2002: National Report. CBS

Gautam, Rajesh and Thapa, Ashok Magar 1994: Tribal Ethnography of Nepal (Vol.1), Book Faith India, Delhi.

Gurung, Ganeshman 2041: Dura Jatiko Samajik Adhayan, Pub. Suresh Bahadur Shahi, Dolpa, Dura Pariyar, Lamjung

Gurung, Ganeshman, 1989: The Chepangs: A Study in Continuity and Change, Published by S.B. Shahi Sanepa, lalitpur

Joshi, Satyamohan 2027: Lok Sanskriti Sarvechan Yesko Bhumika Ra Yes Sambhandhi Paricharcha, Pragya, Kathmandu

Madge,Leila 1985-86: The Dura of Sindure: Perspective of Ethnicity (Unpublished), University of Wisconsin, College Year in Nepal.

National Planning Commission HMG/N 2059 Tenth Plan.

Parajuli, Krishna Prasad 2047 editor, Nepali Brihat Sabdhakosh, Ne.Ra.Pra.Pra, Kathmandu

Pragya, Ashad-Magh 2051/52: Purnanka 82 ka, Barsha 25-26, Janjati Bishaanka, Ne. Ra.Pra. Kathmandu

Mukherjee, Rabindranath, 1994: Samajik Manavshatra Ki Ruprekha, Vivek Prakashan, Delhi

Mechi Dekhi Mahakali (bhag 3.031): Shree Panch Ko Sarkar, Suchana Tatha Sanchar Mantralaya, Kathmandu

Sharma, Narendra 2037: Nepali Janjivan (Khojgranth), Paramrash Kendra, Lalitpur.

Singh, Narendranath 1994: Gramin Samajshatra, Vivek Prakashan, Delhi

Shrestha, Gyanendra Bahadur, 2049: Parivarik Kanoon, Pairavi Prakashan Kathamndu.

Srivastavea(ed), Tradition And Modernization India, International Publication.

Tamang, Sitaram 2044: Nepalma Janjati Samasya

Thapilaya, Santa 2048: Kanooni Shayaog

Thapa, Dharmaraj 2030: Gandaki Suseli

Thapa, Krishna Bahadur 1982: A Brief Survey Of The Dura Tribe Of Lamjung: A Mini Research Project (Unpublished), History Instruction Committee, T.U Kathmandu.

.......1976: Modernization Among the Tribes of The North Eastern India (Assam) in S.K.

Yogi, Narhari Nath (Bagh 1/012, Bagh 3/013) Itihas Prakash Mandal, Kathmandu 


\section{Notes to Contributors}

Dhaulagiri Journal of Sociology and Anthropology, MMC, Baglung, is a compilation of articles, original research reports, review articles, book reviews, dissertation abstracts, professional announcements, and other information of interest in the areas of sociology and anthropology of Nepal and other regions. Articles may be both Nepalese and foreign scholars. Research articles on current issues in sociology and anthropology are mostly preferred.

Articles should be in English. It should not exceed 4000-6000 words. The title of the paper should be of 14 points bold, sub-topic 12 point bold, and normal text 12 point in Times New Roman (Font). Authors must take full responsibility for the originality, contents, and opinions expressed in their articles, must be suitably acknowledged.

Spelling should follow that of the Oxford English Dictionary or Webster's New World College Dictionary. Words in other language other than English should be in italics. The contributors are requested to maintain consistency throughout their articles.

The text should refer to notes numbered consecutively throughout the article, publication and biographical references should be cited in the text by the author's last name, date of the publication and page number, e.g. (Khatri 2003:54) or if the author's name is mentioned in the text, by the date and page reference only, (2003:54). Entries in the references should be in alphabetical and chronological order: name of the author (s)- surname first, date, title, name of the periodical, Volume number (Arabic numerals to be used throughout), place of publication (and name of the publisher for a book). Examples of reference format are as follows:

Tiwari, Sudarsan Raj, 2001. The Ancient Settlements of the Kathmandu Valley. Kathmandu: Centre for Nepal and Asian Studies, Tribhuvan University.

Mishra, Chaitanya, 1984. Social Research in Nepal: A Critique and Proposal. Contribution to Nepalese Studies Vol 11 (2), pp1-11.

Shrestha, Bal Gopal, 2002. "The Ritual Composition of Sankhu: The Socio-Religious

Anthropology of Newar Town in Nepal”. Unpublished PhD. Thesis. Leiden University.

Contributors are requested to send, if possible, their materials on computer floppy disks using IBM compatible word processing programs. They, however, are requested to send a copy of the manuscript separately as a hard copy. The text, notes, and references should be typed double-spaced. The title of the paper, authors name, affiliations, and complete address should appear on the first pages.

All correspondences related to editorial and subscription should be addressed to:

The Chairperson

Department of Sociology/Anthropology

Mahendra Multiple Campus, Baglung.

Email Address: soanbaglung@yahoo.com 